\title{
Translation as Liberal Art: Four Voices
}

\author{
Mahmoud M. Gewaily \\ Minia University, Egypt
}

Received: 15-09 - 2013

doi:10.7575/aiac.ijclts.v.1n.3p.6
Accepted: 05-10- 2013

Published: 15-10-2013

URL: http://dx.doi.org/10.7575/aiac.ijclts.v.1n.3p.6

\begin{abstract}
This paper delivers to the reader something of the drama that was at the centre of the colonized countries, from beginning to end. It seeks to conceive the individual art of the indomitable Martinican poet and dramatist Aimé Césaire (1913-2008), for writing one of the classics of Caribbean writing -- A Tempest (AT). A strong social and political conscience informs the play, hoping to liberate the literary mind of Césaire against the classical colonial ambition of the disturbing work of Shakespeare-- The Tempest (TT). The key question to this paper is: how each of these two texts, in a feasible dialogic way, shades into one another, and if this new version one adapted with some distance from the original for more imaginative work? Thus, my take has been to deploy the dialogic ideas of the language philosopher Mikhail Bakhtin, specifically the art of answerability. I argue here that Cesaire's call for a reclaiming of a self-other duality marks as a force for social change and liberation.
\end{abstract}

Keywords: Translation adaptation, postcolonial, retrospect, prospect, resistance, empire

1. Prologue: The Liberal Art of Answerability

My purpose is to address the art of answerability in the postcolonial literature as a liberal art of dialogism between two works of the classics, one on colonialism made by Shakespeare (TT) and the other on postcolonialism remade by Césaire. This self-other relationship, a hard-edged portrait of a contemporary crisis and a confronting exploration of Prospero's and Caliban's lives, brings us into a world that is shocking, with a gaze that is unflinching but compassionate.

I have chosen Bakhtin to address the art of answerability through drama as a particular genre.That is, my purpose is, first, to examine whether the acts of translation as recreations of the past that are moving towards the future, can provide an urgent, and thus important, effect as it helps to produce anti-colonial arguments that can ultimately do convince. Second, it all boils down to see how the writer has achieved his effect, to appraise any creative urge to adapt (AT), which is so steeped that it enlivens the other text of a firsthand outstanding experience (TT), and yet the last word to speak fully the unspeakable agonies will never be said. In this sense, Bakhtin (see Wesling 2003, Holquist 1990 and Dentith 1995, for example) can help us address and think about the dialogic pathways, and through which their development to (post-)colonialism some of the postcolonial translation problems can be marginalized if we look at translation as liberal art - the art of answerability.

Man's imagination, thinking skills and knowledge spring from a brain through which man seeks a meaning in life by a symbolic act of expression of his desires symbolically through the arts. This social act of verbal communication and of non-verbal written communication is true to Bakhtin's thought in a vital sense--the utterance as both the cultural unit and linguistic unit of communication. In "Art and Answerability" (1990: 1), a polemic essay written in (1919), mainly before Bakhtin's Problems of Dostoevsky's Poetics (PDP) (1929/1965/1984), Bakhtin integrates the cultural unit and the linguistic unit in a responsible act of answerability:

A whole is called 'mechanical' when its constituent elements are united only in space and time by some external connection and are not imbued with the internal unity of meaning. The parts of such a whole are contiguous and touch each other, but in themselves they remain alien to each other.

The three domains of human culture-science, art, and life-gain unity only in the [talent of the]individual person who integrates them into his own way. [...] When a human being is in art, he is not in life, and conversely. There is no unity between them and no inner interpenetration within the unity of an individual person. But what guarantees the inner connection of the constituent elements of a person? Only the unity of answerability. I have to answer with my own life for what I have experienced and understood in art.

This particular view of the necessity to answer from an individual perspective stands on the same page of Hogan's view later, to try to answer opposing viewpoints about the problem of colonialism, for example, in their own individual voices. 


\section{VOICES Selected: The Battle over Césaire}

Patrick Hogan (2004, p. 234) suggests an alternative for the realization of how the thematic content of the two texts may be possible to fit or not match: "The relations between an individual work and the various disunified traditions that precede and enable it are multiple and variable, and, if we are to understand the new work, it is necessary to understand these relations." Specifically, Hogan's view bears resemblance to Bakhtin's notion of the ability of the individual person to unify the three domains of human culture (science, art, and life) in his own way, stating that the reader should make a dialogic association between the active consciousness of the authorial talent in the created text and the world as a guide towards a better understanding between the text and its background. Below I will focus attention on the views of three recent scholarships on Césaire alongside the position taken here in this paper in order to bring to light the four dialogue of four voices on the Battle over Césaire.

\subsection{A Live Interaction Celebrated}

First, why Césaire? The selectivity of the particular author Césaire is to give an ideal example of translation as liberal art. Why Drama? The reason for the choice of drama is that it is meant to be played on stage as the oral performance creates a live interaction between a speaker and his audience. This kind of participation is beyond the obligation of Césaire for the cultural integrity of the Caribbean people in the hope of responding to the patterns of thoughts and ideas about colonial hazards. Césaire pays more attention to the problem of postcolonial nations and his literary process "is situated at the intersections of esthetic modernism and black consciousness". Between the two world wars, it was common for the black intellectual elites to meet in the capital of Paris where it was a place for the black writers to meet and celebrate their contribution to the "rehabilitation" of their black world, and where the pioneer Fanon has met with and learnt from Césaire. Further, the Césairean Negritude "operates from a platform where a modernist outlook, revised and corrected in the light of imperatives in the Antillean quest for identity, anchored in the complexities of the Antillean postcolonial condition, encounters the project that would henceforth be celebrated as a cultural renaissance of the black world" (Kemedjio and Mitsch, 2000, p. 213).

\subsection{Adjudication}

Second, the political situation in francophone African countries leading to independence has "inspired", in fact, Césaire to "expand his literary range" to include drama. Hale and Kora (2010) agree that in works such plays as La tragedie du roi Chrisophe 1963; The Tragedy of King Christopher) and Une saison au Congo (1966; A Season in the Congo) as "plays informed by the politics of the past and the present," Césaire "warned his readers and audiences, especially in Africa, of both the internal and external pitfalls on their path to independence." Also, these plays "reflected a new turn in Césaire's outlook as he expanded his range to include a genre that was more accessible to people." Césaire has focused on the art of drama because it is highly accessible to a great number of people, especially the main goal of his poetic and dramatic works aimed "to raise the political awareness of his audience" (2010, pp. 63-64). Hale and Kora contend that the relationship between "Césaire's literary works and his political action needs further study" (2010, p, 46). They have met the problem of the large number of texts to examine in a very limited space so they decided to select a few of the most exemplary that appeared during three periods in Césaire's career 1935-48, 1949-56, and 1957-2009. they (2010, p. 48) go on: "Each marks a different chapter in his life, and also a different relationship between the literary and the political." Furthermore, Hale and Kora (2010, p. 54) draw specific attention to the missed facts about the issue of "Departmentalization" that has "generated considerable debate" as it was criticized by "outsiders as a form of capitulation to the colonial power. What many critics have missed are the difficulties posed by the economic conditions in Martinique, the challenges to of obtaining aid from the government in Paris, the long history of the 's relationship to France, and the contemporary geopolitical situation in the Caribbean at the time."

\subsection{Venturesomeness}

Third, a rereading of Césaire's oeuvre following his death in 2008 made Garraway (2010) stress that she has been "more fascinated by the extent to which Césaire not only anticipates and even undertakes many of the same criticisms concerning the pitfalls of essentialism and the urgency of deconstructing colonial discourse, also he exhibits prescient insights into theoretical debates around subjectivity, identity, difference, and liberation that continue to engage us today" (2010, p. 76). The analytic venturesomeness of Césaire's poetic characterization presents "itself as a violent act of liberation, a war of resistance or struggle to the death, defines much of his subsequent literary production..." (2010, p. 81). Garraway defends the position of Césaire as "a pioneer in the 'practice' of diaspora"; by drawing upon black American, African, and Caribbean cultural influences, as well as French literature and philosophy, Césaire's work produced over a nearly half-century "would gain critical prominence and a wide readership in the Atlantic world across boundaries of language, ethnicity, and nation" (2010, p. 74).

The stance of Garraway is to sponsor the work of Césaire against the view of Fanon by deploying the vocabulary of Fanon in order "to read Césaire as a theorist of colonial dis-alienation whose Negritude is not a fixed object or idea but a dynamic process ... by questioning their authors' insufficiently subtle appreciation of the nuances of Césaire's oeuvre and their occasional confusion of literature with politics or social action" (2010, p. 76). Garraway compares Fanon and Césaire, indicating how the anti-essentialist take of Fanon does not reflect Césaire's particular usage of negritude: "For Fanon, Césaire's work demonstrates the risk that even a strategic essentialism will never achieve real recognition; for if the black can prove himself useful and respectable to whites as pure immanence, he will just as easily be rejected as irremediably stuck in a stage of development that whites in their rational transcendence have long surpassed" (2010, p.75). In essence, Garraway (2010, p.83) goes on next to stress the interfaces of self and the other through Césaire's 
courageous commitment to negotiating between the universal and the particular, the self and the other, when theorizing the construction of an ethical post-slavery, postcolonial community. Whereas poststructuralism critiques universalism, particularism, and the subject and yet offers few political solutions to the problems of postcolonial nations, Césaire chose to advocate a self-reflexive engagement with particularism and [original emphasis] universalism and hoped, in the process, to transform both.

\subsection{The Self \& the Other}

Fourth, my current approach, along with the battle of the aforementioned three voices on Césaire, is to question the act of translation adaptation in defense of Césaire. The way I see cultural adaptation is to create a deeply sedimented but unacknowledged background of a free translation of resistant performance. To address this problem, I turn to the theoretical framework of the Bakhtinian art of answerability in its relation to (post-)colonialism. The claim of Baker (1986, p.190) stresses the firm self-other duality in the relationship between Prospero and Caliban

courageous commitment to negotiating between the universal and the particular, the self and the other, when theorizing the construction of an ethical post-slavery, postcolonial community. Whereas poststructuralism critiques universalism, particularism, and the subject and yet offers few political solutions to the problems of postcolonial nations, Césaire chose to advocate a self-reflexive engagement with particularism and [original emphasis] universalism and hoped, in the process, to transform both.

Along with this foundational view of Baker (1986), this article is about how to reconsider he middle ground in this selfother relation, hoping to see voices in the translation of the speaker's text into the receiver's text, particularly how to use Bakhtin's terms to locate the way answerability works in translation, and how a set of worldviews, of transformations in the deep sense of interlocutions, can reproduce it.

Based on the fact that language, culture (memory), and thought are inextricably intertwined, and the analysis of one relates to others, a study of the conflations between text and its adaptation neatly posits an articulated tool to cultivate the effort in using the relevant type(s) of dialogue between Source Text (ST) and Target Text (TT) to consider the dialogic nature of reception and distance, and how this can reflect the relational view of equivalence and difference. In order to do so, I take up an argument that I come to rethink the translation's role as a cultural concept (in Jakobson's sense 1959) in order to give voice to cultures across various literary efforts. To this end, I develop an argument through a conception of the postcolonial dialogic adaptation in healing the colonial disease by stressing deep feelings of human understanding. The following is a comparison of the performance of two literary texts of Shakespeare (TT) and Césaire (AT), in a retrospect-prospect relationship.

\section{VOICES Reflected: Retrospect}

This comparative analysis of the two plays allows us to see how Lamming, who shares Césaire the Caribbean homeland, envisioned, as well, Shakespeare's play as a way of seeing, of writing back: "[...] it is my intention to make use of The Tempest," stresses Lamming (1984, p. 9) at the night of initiating the experience of writing back, "as a way of presenting a certain state of feeling which is the heritage of the exiled and colonial writer from the British Caribbean [...]". This complaint itself is impressive not only in what it presumes to be important but also in the historical attitude it addresses toward even Western hegemony in which colonies in the past two centuries from different nations representing cultures onward have been suffering and exiled even at their own home.

\subsection{The Master-Slave Relationship}

The character of Prospero exposes the widespread attitude of colonial superiority as the masterful power of authority. In contrast to, and as a result of, TT, the reflections of the characters, Caliban and Ariel, focus on the nature of inferiority by displaying the slave-driven sense of weakness. Shakespeare intends for Prospero to have a long-run belief in the ability of his own magical powers to control nature, a belief that later becomes too difficult to keep. When asking Ariel to account for the damage of the tempest, he responds: "not a hair perished" (TT, p. 102). Prospero pays more attention to Caliban than to Ariel. The authority of Prospero lies in his belief in the power of magic and magical books, without which the set of rules and regulations stated by the master for the slave to follow would not be properly obeyed. In act I, scene 2 of TT, there is the possibility for the ship to be wrecked during the violence and destructiveness of the storm. However, the ship is safe due to the help Prospero intercedes when his daughter Miranda beseeches her father using his magical powers to alleviate the pains and sufferings of those shipwrecked. Prospero responds immediately and assures her that "there is no harm done" (TT, p. 102).

As a result of the master-slave relationships is that Prospero, in TT, gets his redemption through a new life. His counterpart in AT, seeks to revenge and revolt. In Césaire's play, Caliban becomes revolutionary. His counterpart in Shakespeare's play, however, becomes a new person, who feels ecstasy for being forgiven. In Shakespeare's play, Caliban admits that his past life was run mistakenly, in which feelings of hatred and revolt were prevalent. Therefore, he decides to go in quest of wisdom and grace.

\subsection{The Authority of Prospero}

Prospero's acts of enslavement vary. For example, he restricts the natural language of Caliban and teaches him, instead, the master's native language. This restriction may be used as a reference for the reader to the mental colonization of Caliban's culture. Caliban has to learn Prospero's language for understanding the orders dictated to him to be fulfilled, like fetching wood and performing office duties. Prospero wishes to be easily understood. However, Caliban learns to 
express his revolt by cursing in Prospero’s language. "The end plague rid you for learning me your language"” (TT, p. 121). With disgust, Prospero only seems to remember Caliban's acts of rebellion. In Act I, scene 2 of TT, Prospero confesses to Miranda that Caliban's replies are inhuman and rude and he never "yields us kind answer" (TT, p. 118). Also, Prospero speaks to Caliban harshly. "What, ho, slave! Caliban! Thou earth, thou, speak!" (ibid.). This means that both Caliban and Prospero bear feelings of disgust and dissatisfaction towards each other. When Prospero is informed about the plot of his enemies, he is so agitated that he sees Caliban as a devil and decides to get revenge himself: "I will plague them all, Even to roaring" (TT, p. 183). Only roaring, not death, is the ultimate end of Prospero's punishment. Shakespeare conveys to us the meaning that Prospero's belief in the absolute power of magic and his commitment to revenge is questionable. This emphasizes the end of the play when readers and spectators see another personality of Prospero in the same attitude towards life.

\subsection{The Role of Ariel}

In act I, scene 2 of TT, Ariel's full hope is to obtain his freedom from Prospero's enslavement. Ariel recounts his past services in an effort to restrain Prospero from enslaving him more. Ariel recalls the past when he still had committed "worthy service [. . .] no lies, no mistakes, sound without grudge or grumblings" (TT, p. 114). Ariel is entirely loyal in the sudden response to the orders of his master. Lamming describes his loyalty as "a lackey person" (TT, p. 99). Prospero desires to employ Ariel to be his eyes for the events of all others on the island. Prospero can be aware of the plots and affairs of those surrounding him, especially Caliban. The purpose of Caliban's acquiescence in completing such tasks is to get the ultimate end of his liberty one day. He finally succeeds and comes to enjoy emancipation and his full freedom. Meanwhile, as he has no way out at the moment, he must surrender to Prospero's request out of fear of the magic spirits. This power will enable Prospero to foretell the plot of Stephano and Antonio against the King of Naples, "to foresee the danger" (TT, p. 142). Ariel obeys his master's command and Prospero therefore calls him "my industrious servant" (TT, p. 142). In the end, Ariel gets his liberty, when Caliban and Stephano are forgiven (TT, p. 192). As a result, Ariel sings happily like a bee since he may now move everywhere, or fly at any time without limits (TT, p. 193).

In TT, Ariel is presented as a loyal character in contrast to the opposite personality of Caliban who undertakes acts of disloyalty as a reflection of his revolt against Prospero. In Act 3, scene 2 Caliban narrates angrily to both Stephano and Trinculo about how his land was usurped by Prospero, the magician, who is described as a horrible master. "I am subject to a tyrant, a sorcerer that by his cunning hath cheated me of the island" (TT, p. 158). But being loyal to Prospero, Ariel denies Caliban's delegation, calling him a liar. In the meantime, Caliban intends to gain revenge on Prospero. Caliban wages war on Prospero and hires Stephano as his lord in order to convince him of killing Prospero. Caliban suggests that in the afternoon hour of Prospero's sleep he should be assassinated. Caliban's plan for Stephano to kill Prospero denotes his fierce hatred, but what interests Caliban is to put his hand on Prospero's magic book. He instructs Stephano how to kill Prospero, “[...] with a log Batter his skull, or punch him with a stake [...] Remember first to possess his books; for without them he's but a sot, as I am, nor hath not One spirit to command - they all do hate him As rootedly as I" (TT, p. 160). The unseen Ariel overhears the plot and decides to inform his master (TT, p. 161). Caliban is pleased when foreseeing Prospero as possibly "destroyed" (TT, p. 163). That feeling of pleasure is the beginning of Caliban's actual revolution after his long passive surrender to Prospero in fear of acts of magic and torture. In this context, the change that Césaire added to Caliban in his AT is worth to consider next.

\section{VOICES Deflected: Prospect}

In a comparison of the ST and TT, for example, the two texts of (TT) and (AT) have been examined like placing two pieces of paper flat on your table. With a hand on each, using arrows and circles, one can denote a few lines of comparison that can make them crash into one another. it is possible to identify in the TT some stylistic elements linked with, or other elements deviated from, the original ST. In this way, the engagement of the mind's eye about the attitude of Césaire will certainly reveal things about the engagement of the reader's in view of the relationship between the self and the other as well.

\subsection{Caliban as a Source of Threat}

Prospero usually remembers Caliban as a source of threat mainly because he feels Caliban's disgust toward him. As a result of fearing Caliban, Prospero resorted to prejudice, beating and invective, as well as a use of his magic power over others. At the end, Prospero feels that he has not been a tyrant at all and assures Caliban that he will not surrender to Caliban's attempt to make him feel like a tyrant. Caliban views the acts of Prospero as those of a master, but Prospero denies that charge: "I am not in any ordinary sense a master, as this savage thinks," but just the island's "conductor" (AT, p. 66). Sometimes Prospero thinks to leave the island to go back home. Caliban has become agitated when informed that Prospero is on his way to leave. Only through Caliban's resisting reactions, he decides to stay. Prospero informs the nobles of his country then that he has changed his mind, justifying that "my duty, thus, is here, and here I shall stay" (AT, p. 67). Prospero's duty is to defy Caliban. Even more, Prospero intends to resort to force if it is a necessity: "[...] I will answer your violence with violence" (AT, p. 67). Caliban feels that Prospero has succeeded in "imposing" a negative "image of myself: underdeveloped in your words, undercompetent that is how you made me see myself! And I hate that image [...] and it's false! But now I know you, you old cancer, and I also know myself!” (AT, p. 64). For Prospero, Caliban is to blame himself for his indignation for it is because of Caliban's assistance that the tyrannical image of Prospero started to grow. Prospero states "[...] Well, I hate you as well! For it is you who has made me doubt myself for the first time" (AT, p. 66). 


\subsection{The Eye-to-Eye Confrontation}

In act 1 , scene 2, Césaire presents the eye-to-eye confrontation between Prospero and Caliban when they remind each other of favors done in the past that in turn dictate each to be loyal to the other. Prospero's favor lies in teaching him the language of Prospero, but Caliban denies that favor. Rather, Caliban believes that the real purpose of Prospero's teaching is to enable Caliban fulfill orders and duties in Prospero's language, like dish washing. This is the kind of linguistic imperialism that Prospero has imposed upon him; Caliban is extremely disoriented from his native language. This is itself an aspect of exile Caliban states his unwillingness to be taught Prospero's language when Caliban begins repeating "uhuru" (AT, p. 11).

The particular utterance of Uhuru, an invented sign of Caliban's native attitude, is aimed to provoke a storm of protest from Prospero: He repeats it both to defy Prospero's wish for Caliban to live in the exile of Prospero's slave-based language and to curse him and his world. For example, when described as an ugly ape, Caliban's feeling escalated like a monster with that big "hooked nose" that makes Prospero look like "some of vulture with scrawny neck!"(AT, p. 11). For Caliban, the real learning has been kept a secret in the magic books of Prospero, and complains about his inability to read them: "all your science you keep for yourself alone[...]"(AT, p. 12). Caliban's favor for Prospero, however, is to guide Prospero and his daughter to the island and teach him everything about the new and unknown trees, fruits, and birds.

The real purpose of the agitation of Caliban is that he has not yet taken revenge on Prospero. Caliban sees Prospero as "the Anti-Nature!" enemy, and in return he decides to defy him. He is conscious enough to realize that the real success is not in regaining the island of his mother back to him, but in making Prospero feel that Caliban is the strongest. He intends to prove that Prospero's sense of superiority, and the unfair feelings of the inferiority of Caliban, are rooted in the mind of Prospero alone (AT, p. 64). He believes that time of humiliation is over. If Prospero is stronger now because of his magic art, Caliban will be the strongest when he overcomes Prospero: "it's because I know I'll get you" (AT, p. 63).

\subsection{The Role of Ariel Replayed}

In act 2, scene 1, Césaire depicts Ariel a one who intends to lessen the gap between Prospero and Caliban in the mastersalve relationship of the play. Because he is sympathetic to the sufferings of Caliban and Ariel, Césaire inserts a separate scene, changing the Ariel-Caliban dialogue from Shakespeare's play in order to enable Ariel to convince Caliban of tolerance, peace, and brotherhood to be seen and felt as inevitable bases to the realization of peace. It is Ariel's hope that Prospero and Caliban be changed into brothers one day. Therefore, Arial attempts to change Prospero, the tyrant, into a good person with the help of Caliban, who, himself, does not believe in any future change in his enemy's personality. Ariel is presented as disloyal to Prospero, the master, but loyal to the Black culture which is embodied in the rebellious character of Caliban. Ariel presents his loyal duties to Blackness in his support to the black slave Caliban. Ariel's loyalty to Caliban is based on the fact that they are brothers in slavery and in their quest for freedom. Caliban and Ariel prove to be friends to the end.

Caliban and Ariel have the same target, but with "different methods", says Ariel (AT, p. 20). Ariel advises Caliban not to fight Prospero. Caliban considers Ariel's viewpoint of non-violence the outcome of cowardice. Ariel, on the hand, does not mean for Caliban to avoid violence totally nor to be fully submissive. All he hopes is to be tolerant in order to open up a space of home for Prospero to change, in order to make him feel his own conscience: "Prospero is the one we've got to change. Destroy his serenity so that he 's finally forced to acknowledge his own injustice and put an end to it" (AT, p. 22). The resistant character of Caliban motivates him to object to Ariel's offer because "death" is better than "humiliation and injustice" (AT, p. 23). Caliban prefers to die better as a lion than to live as a rat. In contrast, it is Ariel's good effort to reform his master that makes him loyal.

Seeing Ariel upset, Prospero uncovers the definite sense of authority in presenting his own insignificance to the humanity and feelings of the slave and the actual tasks. Prospero's full interest is not in Ariel's "mood" but in his "deeds" (AT, p. 9). Prospero determines to embarrass Ariel by not letting him forget the duties of the salve to the master. Prospero reminds Ariel to show him gratitude for freeing him, in the past, from Syncorex. So, Ariel is indebted to his master in the sense of fulfilling Prospero's needs and orders unquestionably. When asking for freedom, Ariel is accused of ingratitude. Ariel thinks that only when Prospero is "good and ready," the gain of freedom could have been fulfilled one day(AT, p. 10). Ariel has no way but to keep waiting, surrender to the orders of Prospero, especially at the very tough time of hard treatment from his master (AT, p. 59).

\subsection{Prospero's Calm Reaction towards Caliban}

Prospero's relationship to Caliban in AT is quite different from his relationship to Ariel. Prospero shows a sense of respect towards Caliban, which is lost in Shakespeare's TT. Moreover, there is no initial reference to Caliban as a slave. Instead, Prospero tells Ariel to meet "Master Caliban" (AT, p. 10). Shakespeare does not refer to Prospero's verbal statement of Caliban's freedom, whereas Césaire refers to not only this freedom, but also Prospero's signs of respect for Caliban. Prospero describes Caliban getting "a little too emancipated" (AT, p. 10).

Prospero tries to persuade Caliban to be a brother: "come, let's make peace" (AT, p. 63). Césaire seeks to establish peaceful moments and to erase negative feelings that had lead to the real sense of alienation and displacement between Caliban and Prospero. But, yet, Caliban does not accept Prospero's offer of peace because Caliban finds his identity had been stolen by Prospero for so long. In other words, having no control on his own island asserts the loss of Caliban's sense of identity. Therefore, Caliban uses the name of $\mathrm{X}$ instead of the given name in order to stress the 
already lost identity. Prospero has no option but to encounter Caliban and finally decides to fight him. The fact that Prospero decides to fight is a proof of Caliban's success to make things hard for Prospero to accept that both accept to get into a fight. Their fight is both a blessing and a disaster.

\section{VOICES Coalesced: The Two Tempests}

The artists's pursuit to bridge cultures in the literary thought is an ethical one, based on the fateful concern of a fulfilment of responsibilities. Earlier, an analysis of Cesaire's AT in light of his critique of Shakespeare's TT indicates how the two plays are polyphonic in nature. This stance of the article examined so far states the ruthless but officially forgotten struggle that Prospero and Caliban encounter as interlocutors to nurture other voices in identified or dissenting voices in both plays. It remains then to shed key lights on the facets of the two texts.

\subsection{Similarities and Differences}

Césaire's AT resorts to similarities and differences with the original Shakespearian version to set off the master-slave issue clearly. Prospero, in AT, makes us feel the obstinacy of the colonizer over the colonized, and the ion of the new culture of European civilization. In contrast, Prospero, in TT, becomes fully transformed not only because of his inner desire but also because of his inability to alter the course of his life through the power of magic. The natural world is presented as superior to civilization. Shakespeare tries to show how humans try to "control the storm", which only can be controlled by the Almighty. Since the Almighty is the only entity that can control the world, revenge should be transformed into forgiveness in both plays.

In Shakespeare's play, Caliban admits that his past life was run mistakenly, in which feelings of hatred and revolt were prevalent. Therefore, he decides to go in quest of wisdom and grace. At the end of TT and AT, Ariel receives his freedom as well. Indeed, the master-slave relationship is highly considered in the two great plays of Shakespeare's (TT) and Aimé Césaire's (AT). The goal here is to show the two plays in depth so as to present how which is considered an interlocutor to the two texts of Shakespeare and Césaire, in view of the master-slave relationship, in order to establish points of leverage to be able to match the criticism of Lamming mainly with the text of Césaire's AT. At the end of TT and AT, Ariel receives his freedom as well.

Prospero is encouraged to transfer his language and a set of practices to his two slaves, Caliban and Ariel. Therefore, it follows the revolutionary nature of a slave, as a human being, by displaying acts of anti-slavery for emancipation and freedom. While there is great stability explicit in the defiant reaction of the slaves, the issue of a solid personal identity for each slave is structured in both plays. The outcome of the master-slave relationships is that Prospero, in TT, gets his redemption through a new life. His counterpart in AT, seeks to revenge and revolt. In Césaire's play, Caliban becomes revolutionary. His counterpart in Shakespeare's play, however, becomes a new person, who feels ecstasy for being forgiven.

\subsection{Keeping the Dream Alive}

Prospero always remembers Caliban as a source of threat mainly because the latter knows the nature of his native island better than the former. In dealing with the Caribbean colonial setting, Césaire adopts the method of alteration and change to emphasize the political and social purposes of the play. The author introduces changes to the two characters of Prospero and Caliban, but with little change to Ariel's, a mulatto slave, especially in Ariel-Caliban the relationship, but considered Caliban his brother in blackness. Césaire also adds Eshu, considered a black devil god. Prospero does not believe fully in one absolute magical spirit like his counterpart in Shakespeare's TT, because of his belief in the fate to be in the hands of God, not in magic. Whether good or evil may occur, fate is considered good and better for Césaire's characters to willingly surrender (AT, p. 6). In the hands of God

In essence, there is a call for national unity and cooperation in every moment when all the world's dominant Calibans resist against the Prosperos as representative of the British hegemony. In this respect,Roxanna Curto (2011, p.169) recognized the ned to warn the people of the colonies against the main assumption of only seeing Prospero as a model of "European colonialism, but of American neocolonialism, which is based on refusal to share with the Carribean peoples the technology that makes political domination possible." Of course, those are multiple texts, to repeat Innes (2000), that seek to reflect how the literary talent of writers reveals various responses to Shakespeare's view of the life in the exile views of postcolonial writers. Comparatively, the examination of how Césaire's AT reflects the liberal genius art of Shakespeare's TT can be seen from the genius of art as a productive art of rhetoric.

\subsection{Adaptation IS Persuasion}

Like Césaire, playwrights can focus on other adaptations of TT (or any other classic by playwrights in different colonial settings) have served the domesticated cultures as they commit to heal the feeling and thought of people by setting their colonized minds at rest. Insights like these, and how the new version abounds, are what make such AT a critique that tends to drop out of the picture the painful colonial fantasies in the past. In this regard, the message does offer us any very strong sense of how the anti-colonial Caribbean responses may have differed in specific ways from the British colonial sites of exile with the passing of colonies long years ago. Through this polemical intent of the usage of adaptation as a voyage of his essentialist experience of Negritude, Césaire's potential response to resist the colonizer's refusal of recognition liberates his homeland.

The country still needs, however, to find ways to think a little about the ceaseless traps of neocolonialism (once they enter, they will never leave) as a threat! It's no coincidence to discuss Garraway's reference to the risk of Fanon in the 1960s and the white's rejection of the black essentialism. This reference to such risk might form the fabric of modern 
society if it could be read in connection with the received threat of both the tearing message of Curto against the immediate American neocolonialism (2011) and the "Caliban's triple play," nearly two decades ago (Baker, 1984, p. 196): which "clears the (U.S.) bases in Third World geographies, providing space for poetry, a song, a sound rather than a sight, cite, or site for further Western duels-and dualities.” By far, neither the most controversial of Fanon's response to the Césairian oeuvre nor even the Césairian way of seeing the best way to present the spatial-temporal reality of the sixties on should be blamed. Rather, the postcolonial ambition of some countries, along with the camouflage of neocolonialism, as threats against the call to national unity, would be better blamed instead. In this sense, Cesaire has well reproduced an imaginative asylum out of the Shakespearian text as a modern refraction of rewriting fate. This is the eloquent act of the pleadings for a national unity.

\section{Final Voyage}

As we have seen, the content of this paper tells the story of the Calibans, namely the agitated politicians of the Caribbean who were fired by a determination to employ the liberal art of writing to lift their people up to a higher level. I have tried to show whether the new version of Césaire through the method of adaptation and transformation is, more or less, well documented and culture-specific. It is through such an articulation of the art of answerability, making escape almost possible for those plunged into darkness, that adaptation as a liberal art of answerability can advance a spirit of stewardship, one that evidences the way translation adaptation as liberal art is inseparable from the philosophy of anti-colonial resistance and postcolonial subjectivity. The findings of this voyage present, at least, a set of four main translation polyphonic voices, each of which has been appropriately identified in tune to the profile of translation adaptation. Even putting into focus an objective comparison of how a modified version of Shakespeare's text through Césaire's text suits the Caribbean recreation of looking at the future, was prolific almost to the point of being liberal.

Thus I shall not propose a conclusion here, as this article is part of an ongoing enterprise. ${ }^{1}$ Rather, attempt to clarify that the proliferation of Bakhtin's own terms (Bakhtin, 1984) will not turn against my position here as they seem completely adequate. (In particular, the gamut of the four voices suggest that the pursuit of the people after independence towards the concept of nation can be only fulfilled, if it resides fundamentally in a self-understanding of humanity presented through both an exemplary configuration of the Cesarian approach towards bonds of national unity, and an open dialogue to ascertain a cross-cultural respect of the symbolic unity of the dual identity and difference as metaphors we live by.) In this way, the both-and, not the either-or, take, as part of Bakhtin's terms, will continue to hold sway over the imagination of wide readership, possibly because they have become not only more vivid, more alive with people, places and talk, but also an open icon of the ideas of the world and about the world, in a retrospect-prospect relationship. Needless to say, it is always Bakhtin's view that everything will always be in the future.

\section{References}

Baker, H. A. (1986). Caliban’s Triple Play. In CriticalInquiry. 13.1: (182-196).

Bakhtin, M. (1994). Discourse in Life ad Discourse in Art. In Elbow. (Ed.), Landmark Essays on Voice and Writing. Mahwah, NJ; Hermagoras Press: 3-10.

----. (1990). Art and Answerability. Michael Holquist \& Vadim Liapunov, (Eds.). Vadim Liapunov \& Kenneth Brostrom, (Trans.). Austin: University of Texas Press.

Césaire, A. (1992). A Tempest. New York: Editions du Seuil.

Curto, R. (2011). The Science of Illusion-making in Aimé Césaire's La tragedie du roi Christophe and Une tempete. In Research in African Literatures. 42.1 (154 - 171).

Dentith, S. (1995). Bakhtinian Thought: An Introductory Reader. London: Routledge.

Emerson, C. (1984). Editor's Preface. In Emerson., (Ed. and trans.). Problems of Dostoevsky's Poetics. In Mikhail Bakhtin. 9th ed. Minneapolis: U of Mota P: xxix- xliii.

Garraway, D. L. (2010). 'What Is Mine': Césairean Negriture between the Particular and the Universal. In Research in African Literatures. $41.1(71-86)$.

Hale, T. A., \& Veron, K. (2010). Is there Unity in the Writings of Aimé Césaire? In Research in African Literatures. $41.1(46-70)$.

Garraway, D.L. (2010). 'What Is Mine': Césairean Negriture between the Particular and the Universal. In Research in African Literatures. 41.1 (71 - 86).

Holquist, M. (1990). Dialogism: Bakhtin and His World. London: Routledge.

Jakobson, R. (1959). On linguistic Aspects of Translation. In Reuben A. Brower, (Ed.). On Translation 23. Cambridge: Harvard UP: 232-39.

Kemedjio, Cilas, Mitsch, R. H. (2000). Aimé Césaire. In Research in African Literatures. 31.2 (213 - 214).

Lamming, G. (1984). The Pleasures of Exile. ( $2^{\text {nd }}$ ed.). London: Michael Joseph.

Shakespeare, W. (1987). The Tempest. Stephen Orgel, (Ed.). Oxford UP.

Wesling, D. (2003). Bakhtin and the Social Moorings of Poetry. Lewisburg: Bucknell UP.

\footnotetext{
${ }^{1}$ To what degree Bakktin's efforts pave the way for our own through a portfolio of interdisciplinary studies to put the interfaces of equivalence and identification in literary stylistic and translation discourse into practice remains to be seen.
} 